\title{
LAW STUDENTS AND LAWYERS WITH MENTAL HEALTH AND SUBSTANCE ABUSE PROBLEMS: PROTECTING THE PUBLIC AND THE INDIVIDUAL
}

This Article is dedicated to the memory of Stanley Herr and his unrelenting work on this issue.

\section{Laura Rothstein*}

\section{INTRODUCTION}

The practice of law is a high-prestige, high-income, high-skill, and highstress profession. Lawyers provide important professional services to members of the public - services that can affect life and death and important matters in the lives of others. Whether because of the personalities of those who choose to enter the legal profession, professional pressures, or a combination thereof, there are significant concerns within the legal profession about the impact of stress on mental health and about substance abuse problems. ${ }^{1}$

* Professor and Distinguished University Scholar; University of Louisville Louis D. Brandeis School of Law. B.A., University of Kansas; J.D. Georgetown University.

This Article grew from my involvement with two separate projects, which have related goals. I am a member of the Milbank Fund Physician Depression and Suicide Prevention Project (2004-present), which focuses attention on why there is such a high incidence of physician suicide and what might be done about it. See Herbert Hendin et al., Licensing and Physician Mental Health: Problems and Possibilities, $93 \mathrm{~J}$. Med. Licensure \& Discipline 6 (2007) [hereinafter Hendin et al., Licensing and Physician Mental Health]. Before that project, I was a member of a workgroup of the American Bar Association Commission on Lawyer Assistance Programs (CoLAP), which focused on constructive ways to provide support to lawyers suffering from alcohol and substance dependency. The involvement in both projects is a result of my work on disability discrimination generally, with focused work on issues relating to higher education and professional licensing.

The Article was the basis for remarks made at the September 7-8, 2007, Emory Conference on Ethics and Professionalism on Lawyers and Disability. At that conference, many of the speakers helped focus some of the discussion in this Article. In particular, I am indebted to Sam Bagenstos, Susan Daicoff, Wendy Hensel, John Jacobi, Michael Perlin, Kelly Timmons, and Michael Waterstone (whose remarks addressed related issues), and my co-panelists Kertia Black, Richard Limoges, and James Thompson (who joined with me in a roundtable comparing the law and medical professions).

Appreciation is also expressed to my colleague, Professor Linda Ewald, who provided information about lawyer discipline and the relationship to mental health and substance abuse, and who was a sounding board for discussing issues raised in the Article. In addition, Robert Sabalis, Associate Vice President, Student Affairs and Programs, Association of American Medical Colleges, was very generous in discussing 
It is difficult to obtain precise data on the incidence of mental illness or substance abuse in the legal profession. Information from various sources, however, seems to indicate that lawyers have a high rate of depression, possibly close to four times the rate of the general population. ${ }^{2}$ The incidence of substance abuse (both alcohol and drugs) is higher for lawyers than the population as a whole. ${ }^{3}$ Some studies are also available about law students. ${ }^{4}$

this topic with me and providing insights on medical school education issues. The Honorable Robert $\mathrm{L}$. Childers, Chair of the ABA Commission on Lawyer Assistance Programs, was very kind in providing me updated information on the Conditional Admissions proposal. My husband, Mark Rothstein, also reviewed and commented on drafts and provided helpful perspectives. I also thank Dean Jim Chen, the University of Louisville Louis D. Brandeis School of Law library support staff, and the University of Louisville Distinguished Scholar program for providing research support. I also thank Rebecca Wenning and Marilyn Peters for their administrative assistance.

My greatest appreciation is expressed to Emily Wang Zahn, my research assistant, for her exemplary and dedicated research, which went above and beyond expectations.

1. See Susan Daicoff, Lawyer, Know Thyself: A Review of Empirical Research on Attorney Attributes Bearing on Professionalism, 46 AM. U. L. Rev. 1337, 1416-17 (1997) (discussing external stress of law school and internal personality traits which are maladaptive as interacting causes of law student distress). Daicoff suggests this theory may be true of lawyers also. She also discusses personality traits that tend to intensify lawyer stress levels. These are "lack of flexibility, intolerance for change, an unbalanced commitment to work and personal life, a belief that destiny cannot be controlled, hostility, cynicism, aggression, fear, low self-esteem, person-centered values, and altruistic social concerns." Id. at 1417 (citing Amiram Elwork, Stress Management for Lawyers 3-5 (1995)). See generally Elyn R. Saks, The Center Cannot Hold: My Journey Through Madness (2007); James T.R. Jones, Walking the Tightrope of Bipolar Disorder: The Secret Life of a Law Professor, 57 J. Legal Educ. 349 (2007); Carol Langford, Depression, Substance Abuse and Intellectual Property Lawyers, 53 U. Kan. L. Rev. 875 (2005); Coe Swobe, Dealing with the Difficult Lawyer: Stress, Addictions, Success Fatigue, 12 Nev. Law., Feb. 2004, at 24 ; Patrick J. Schiltz, On Being Happy, Health, and Ethical Member of an Unhappy, Unhealthy, and Unethical Profession, 52 VAND. L. Rev. 871 (1999).

2. See W.W. Eaton et al., Occupations and the Prevalence of Major Depressive Disorder, $32 \mathrm{~J}$. OcCuPational Med. 1083-1132 (1990) (studying more than 100 occupations).

3. It is suggested that attorneys may have addiction rates $(15-18 \%)$ higher than the general population (9.4\%). See Doug Taft, Impaired lawyers overcome denial, stigma to achieve road to recovery, HAZELDEN VOICE, Summer 2004, http://www.hazelden.org/web/public/vcsum4lawyers.page; Elsie R. Shore, The Relationship of Gender Balance at Work, Family Responsibilities and Workplace Characteristics of Drinking Among Male and Female Attorneys, 58 J. Stud. Alcohol 297 (1997) (sampling attorneys about influence of gender on drinking behaviors); Robert D. Resner, Addiction and the Legal Profession, in CALIfornia MCLE Marathon 2006: Latest Issues in Legal Ethics-Substance Abuse-Elimination of Bias in the Profession 317 (Pli Litig. and Admin. Practice, Course Handbook Series No. 9012, 2006) (providing data on the magnitude of the problem, estimating that the incidence of chemical dependency is between $15-18 \%$ in the legal profession, compared to $8-10 \%$ of the general population; noting that $50-70 \%$ of cases of lawyer discipline involve alcoholism and/or addiction; discussing treatment and assistance programs); see also R.H. CoOmBs, DRUG-IMPAIRED Professionals (1997) (describing the nature of substance abuse among professionals, self-destructive dynamics, and recovery tools and programs).

4. An AALS Special Committee on Problems of Substance Abuse in the Law Schools reported the prevalence of substance abuse in law school as significant and raised very serious concerns. See Report of the AALS Special Committee on Problems of Substance Abuse in the Law Schools, 44 J. Legal Educ. 
Because of the high stakes involved in the legal profession and the stigma attached to mental illness and substance abuse problems, individuals with these problems are often reluctant to seek help.

Even if the prevalence of mental illness and substance abuse problems are no higher for lawyers compared with the general population, the consequences of such impairment are significant. ${ }^{5}$ The stakes are high for lawyers themselves, who expend significant amounts of time and money obtaining the credentials to practice law. Legal educators, employers, and regulators have a strong interest in protecting clients and the public from adverse events that might result from a lawyer's impairment. They also have an interest in protecting their credibility by assuring the public that they are appropriately monitoring misconduct. Clients have the highest stake in ensuring the competence of the lawyer providing the service because clients' lives are often affected in significant ways by the competence of the lawyers representing them. ${ }^{6}$

Part II of this Article provides an overview of the policies, practices, and procedures that affect individuals with mental health and substance abuse impairments at various stages of entering and continuing in the legal profession. Part III reviews how these policies are applied in the admission to and enrollment in law school. Part IV focuses on professional licensing, both initially following completion of law school and as an ongoing process. Part V addresses the employment issues that arise for lawyers.

This Article evaluates whether mental illness and substance abuse policies, practices, and procedures appropriately balance the concerns of the individual lawyer with the interests of the public. This Article concludes by offering recommendations to improve the handling of these issues and suggestions about areas where additional study is needed. ${ }^{7}$

35, 40-44 (1994) [hereinafter 1993 AALS Report] (describing survey data). Data on medical school students is discussed in J. Hall et al., Treatment of Alcohol Dependent Physicians: Impact of Alcohol Use During Medical School, 51 Biol. Psychiatry (8S) 197S (2002); B.D. Rowley \& D.C. Baldwin, Substance Abuse Policies and Programs at U.S. Medical Schools, 63 J. Med. Educ. 759-61 (1998).

5. See generally John Freeman, Turning in Impaired Lawyers for Misconduct, 15 S.C. LAW., Jan. 2004 , at 9.

6. ABA Comm'n on Impaired Attorneys, An Overview of Lawyer Assistance Programs IN THE UNITED STATES (1991) (estimating that $40-75 \%$ of disciplinary complaints result from substance abuse or mental health problems).

7. Interesting comparisons can be drawn with the medical profession. See Marie R. Baldisseri, Impaired Healthcare Professional, 35 CRITICAL CARE MED. S106 (2007) (presenting data indicating level of misuse of drugs or alcohol and comparing types of usage by medical students and residents and attending physicians; estimating that $10-15 \%$ of all healthcare professionals misuse drugs during their career, $6-8 \%$ physicians have substance use disorders, up to $14 \%$ have alcohol use disorder - all figures that are similar 
Mental illness and substance abuse raise different issues, but they are treated together in this Article because both have the potential to result in significant impairment affecting an individual's professional conduct. In some instances, the mental illness or substance abuse may be triggered by similar kinds of stress. The response in terms of treatment and consequences will depend on the diagnosis, but the focus should nonetheless be primarily on the conduct.

This Article does not attempt to address the issue of why legal education and the legal profession produce so much stress. While it is certainly an important and related topic, others have addressed that issue. ${ }^{8}$ This Article focuses on the results of the stress on the individuals and how the profession has responded.

to the general population; concluding that recovery rates for impaired healthcare professionals seem higher compared with other groups).

Health care professionals seem to have rates of substance abuse similar to the general population, although their use is slightly higher than other professions. See A. Mavrofour et al., Alcohol and Drug Abuse Among Doctors: A Review of the Literature, 25 J. Med. \& L. 611 (2006) (indicating higher incidence among anesthesiologists, possibly because of easier access to certain drugs; discussing factors that may relate to drug and alcohol abuse); Tracy Hampton, Experts Address Risk of Physician Suicide, 294 J. Am. MED. Ass'N 1189 (2005) (discussing prevention of physician suicide and barriers to prevention); Genevieve Monahan, Drug Use/Misuse Among Health Professionals, 38 Substance Use \& Misuse 18,771 (2003) (discussing what leads to use and misuse, consequences, and treatment; addressing the consequences of seeking help); Claudia Center et al., Confronting Depression and Suicide in Physicians: A Consensus Statement, 289 J. Am. MED. Ass'N 3161 (2003) (concluding that the culture of medicine does not give a high priority to physician mental health; noting the barriers to treatment); Stephen Ross, Identifying an Impaired Physician, VIRTUal Mentor, December 2003, http://virtualmentor.ama-assn.org/2003/12/cprl10312.html (discussing physician health programs and their viability in providing treatment for substance abuse); Eugene V. Boisaubin \& Ruth E. Levine, Identifying and Assisting the Impaired Physician, $322 \mathrm{~J}$. Med. ScI. 31 (2001); Deborah Brooke, Impairment in the Medical and Legal Professions, $43 \mathrm{~J}$. Psychosomatic Res. 27 (1997) (describing the occupational risk factors that facilitate substance misuse by doctors and lawyers and the professional consequences of addiction; noting that specialties such as emergency medicine, psychiatry, anesthetics, and high stress nursing specialties are at higher risk); Joan M. Brewster, Prevalence of Alcohol and Other Drug Problems Among Physicians, 255 J. Am. Med. Ass'N 1913 (1986) (estimating the incidence at 8-14\%).

Research shows gender differences in impairment. Baldisseri, supra note 7, at S108 (stating that female physicians are more likely to abuse alcohol than prescription drugs).

8. See generally Lawrence S. Krieger, What We're Not Telling Law Students and Lawyers-That They Really Need to Know: Some Thoughts-in-Action Toward Revitalizing the Profession From Its Roots, 13 J.L. \& Health 1 (1999). A symposium issue of the Journal of Law and Health includes five articles and commentaries on this issue. See Connie J.A. Beck et al., Lawyer Distress: Alcohol Related Problems and Other Psychological Concerns Among a Sample of Practicing Lawyers, 10 J.L. \& HeAlth 1 (1995); James J. Alfini \& Joseph N. Van Voreen, Is There a Solution to the Problem of Lawyer Stress? The Law School Perspective, 10 J.L.\& Health 61 (1995); Peter G. Glenn, Some Thoughts About Developing Constructive Approaches to Lawyer and Law Student Distress, 10 J.L. \& Health 69 (1995); Geoffrey C. Hazard, Jr., Commentary: Policy Implications, 10 J.L. \& HeAlth 79 (1995); Susan C. Locke, Lawyer Distress: A Comment, 10 J.L. \& Health 87 (1995). 


\section{Policies, Practices, And Procedures-An Overview}

This section contains an overview of the policies, practices, and procedures that apply to mental impairment and substance abuse within the legal profession. The discussion of "policies" includes official legal policy as mandated by statutes, regulations, and judicial interpretations. It includes policies implemented by national organizations (e.g., standards) as well as policies of institutions (e.g., state licensing boards, educational programs, and employers). The policies discussed include those relating to disability discrimination, employment qualifications, privacy and confidentiality of medical records, discipline, intervention, treatment, and education.

The discussion of "practices" addresses what is actually done by a particular entity in carrying out a policy. Particularly where specific policies do not exist, the general practice is important; but even where policies exist, it is important to consider whether the policies are actually implemented and how. Practices include guidelines and model practices, which are not necessarily mandatory.

The issue of "procedures" overlaps with both policies and practices. In some instances, a policy may mandate a particular procedure to be followed. In others, the procedure will be developed in order to carry out the policy. Some practices may become de facto procedures.

\section{A. Statutory and Regulatory Guidance}

Individuals with disabilities in the legal profession are protected against discrimination by two major federal laws. ${ }^{9}$ Section 504 of the Rehabilitation Act of 1973 (Section 504) ${ }^{10}$ prohibits discrimination by programs receiving federal financial assistance. State governmental agencies that receive federal funding and most universities that receive assistance for student loans and grants are subject to Section 504. Because they do not receive federal financial assistance, most law firms, corporate employers of lawyers, and other private employers are not subject to Section 504.

The Americans with Disabilities Act (ADA) ${ }^{11}$ was enacted in 1990 in large part to address gaps in the Rehabilitation Act. Its three major provisions

9. There are also a number of state laws that may provide protection. Most states laws are similar to federal laws. A detailed discussion of these is beyond the scope of this Article.

10. 29 U.S.C. $\$ 794(2000)$.

11. 42 U.S.C. $\S \S 12101-12213$ (2000). 
are Title I (applying to employers with fifteen or more employees), ${ }^{12}$ Title II (covering state and local governmental agencies), ${ }^{13}$ and Title III (covering twelve categories of private providers of public accommodations). ${ }^{14}$ Title I applies to employment in both public and private law schools. Title II applies to state law schools and to state agencies that employ lawyers. Licensing agencies for the legal profession are state agencies. Although they do not receive federal financial assistance and are thus not subject to Section 504, they are subject to the ADA requirements under Title II. ${ }^{15}$ Title III applies to private law schools. ${ }^{16}$

Both the Rehabilitation Act and the ADA have similar definitions of covered individuals. ${ }^{17}$ Both laws prohibit discrimination on the basis of disability against otherwise qualified individuals with disabilities. ${ }^{18}$ The individual must have a "disability" to be protected. A person with a disability must have an impairment that substantially limits one or more major life activities, be regarded as having such an impairment, or have a record of such a condition. ${ }^{19}$ The individual must be able to carry out the fundamental requirements of the program, or employment position, with or without reasonable accommodation. ${ }^{20}$ The program or employer is not required to lower standards or fundamentally alter the program to accommodate the disability. ${ }^{21}$ There is no duty to provide accommodations that are unduly burdensome. ${ }^{22}$ Individuals who are a direct threat to self or others may be

\footnotetext{
12. Id. $\S 12111-12117$.

13. Id. $\S \S 12131-12165$.

14. Id. $\S \S 12181-12189$.

15. For a discussion of licensing under the ADA, see LaURa Rothstein \& Julia Rothstein,
} Disabilities AND THE LAW $\S 5: 8$ (3d ed. 2006). In 1997, Congress considered exempting the medicallicensure process and judicial-candidate screening from Title II of the ADA. After hearings on this matter, no change was made. See The Application of the Americans with Disabilities Act to Medical Licensure and Judicial Officers, Hearings Before the H.R. Subcomm. on the Constitution (May 22, 1997), available at http://commdocs.house.gov/committees/judiciary/hju52589.000/hju52589_0f.htm (including testimony from various perspectives on the advisability of such a change; focusing on broad questions on treatment and diagnosis).

16. $\S 12181(7)(\mathrm{J})$.

17. See generally Rothstein \& Rothstein, supra note $15, \S 1: 10$, at 33 .

18. 29 U.S.C. $\S 705(20)($ A)-(C); 42 U.S.C. $\$ 12102(2)$.

19. See supra note 18.

20. Se. Cmty. Coll. v. Davis, 442 U.S. 397, 407 (1979). For a detailed discussion of this case, see Laura Rothstein, Southeastern Community College v. Davis: The Prequel to the Television Series "ER," in EduCATION STORIEs (2007).

21. Davis, 442 U.S. at 413.

22. §12111(10)(A); see also Wynne v. Tufts Univ. Sch. of Med., 932 F.2d 19 (1st Cir. 1991); Zukle v. Regents of the Univ. of Cal., 166 F.3d 1041, 1048 (9th Cir. 1999). 
found not to be otherwise qualified. ${ }^{23}$ Individuals who are alcoholics are protected if they are able to perform the duties of the job and there is no direct threat to the property or safety of self or others. ${ }^{24}$ This does not require programs to excuse performance deficiencies or to prohibit being impaired by these substances during their participation in the program. ${ }^{25}$ An individual that is currently engaged in the illegal use of drugs is not protected under either the $\mathrm{ADA}^{26}$ or the Rehabilitation Act. $^{27}$

The courts, including the Supreme Court, have focused substantial attention on the definition of who is covered and other aspects of disability discrimination law. In 1999, the Supreme Court established that, in deciding whether someone has a substantially limiting impairment, the court should take into account mitigating measures (e.g., eyeglasses or medication). ${ }^{28}$ As a result, many conditions such as epilepsy, diabetes, and mental illness are now routinely found by courts not to be covered. Although the determinations must be based on individualized assessment, the trend towards narrowing coverage is clear. ${ }^{29}$ Thus, the courts often do not reach the issue of whether the individual is otherwise qualified or whether reasonable accommodations must be provided. A number of cases have been decided in the context of law students in their educational programs, in the legal licensing process, and in the employment setting for lawyers. ${ }^{30}$

In addition to these two major statutes relating to nondiscrimination, there are a number of other federal laws that have implications for impaired professionals. These include laws relating to privacy, treatment, discipline, and other issues, as discussed below.

Individuals with disabilities are understandably concerned about discrimination that may result if others know about their impairments. This is particularly a concern when conditions are stigmatizing, such as mental illness or addiction to licit or illicit substances. Thus, there are legitimate

23. § 12113(b); see also Chevron U.S.A. Inc. v. Echazabel, 536 U.S. 73 (2002). The threat must be based on reasonable medical judgment relying on current medical knowledge, not on untested and pretextual stereotypes. 29 C.F.R. § 1630.2(r) (2007).

24. 29 U.S.C. $\S 706(8)(C)(v) ; 42$ U.S.C. $\S 12114$.

25. 29 U.S.C. $\S 706(8)(C)(v i) ; 42$ U.S.C. $\S 12114$.

26. $\$ 12114$.

27. $\$ 706(8)(C)($ iii).

28. Three Supreme Court decisions, known as the "Sutton trilogy," narrowed the definition of who is covered under the ADA and the Rehabilitation Act. See Sutton v. United Air Lines, 527 U.S. 471 (1999); Albertson's, Inc. v. Kirkingburg, 527 U.S. 555 (1999); Murphy v. United Parcel Serv., Inc., 527 U.S. 516 (1999).

29. See Rothstein \& Rothstein, supra note $15, \S \S 4: 8$ to :9, at 383-416.

30. Id. $\S 5: 8$, at 510. For cases involving medical students, see $i d$. $\S 10: 3$, at 693 . 
concerns about who has access to records about these conditions. In the higher education context, such information is protected by the Family Education Rights and Privacy Act (FERPA). ${ }^{31}$ In the employment context, these records are protected under provisions of the ADA and the Rehabilitation Act. $^{32}$ Further protection is found in Health Insurance Portability and Accountability Act of 1996 (HIPAA). ${ }^{33}$ The Drug Abuse Prevention, Treatment, and Rehabilitation $\mathrm{Act}^{34}$ provides for limited disclosure of patient records regarding the identification, diagnosis, prognosis or treatment in drug abuse programs supported by federal government agencies..$^{35}$ Together, these provisions provide some, but not total, assurance of confidentiality to individuals with disabilities. The Drug Free Workplace Act of $1988^{36}$ adds additional requirements to certain federal grant or contract recipients to ensure that covered worksites are drug-free.

The legal profession regulates misconduct through a number of avenues. These include peer reporting systems and other disciplinary systems established by state agencies. ${ }^{37}$ Legal malpractice cases also provide a mechanism for policing misconduct, although these cases will remedy the case of an individual client rather than addressing whether the attorney should be able to continue to practice.

\section{B. Judicial Interpretation}

Substantial judicial attention has been given to the issue of professional licensing boards and the boards' questions about mental health history and substance abuse. Because licensing boards do not receive federal financial assistance, this did not become an issue until the ADA was enacted in 1990. Under Title II of the ADA, licensing boards are considered state governmental

31. 20 U.S.C. $\S 1232$ g. For accompanying regulations, see 34 C.F.R. $\S \S 99.1-.67$ (2007).

32. 42 U.S.C. § 12112 (d); 29 C.F.R. § 1630.14.

33. Pub. L. No. 104-191, 996, 110 Stat. 1936 (codified in scattered sections of 26, 29, and 42 U.S.C). For accompanying regulations, see 45 C.F.R. $\S \S 160.101-.552,164.102-.530$ (2007). Current information on HIPAA is available at www.hhs.gov/ocr/hipaa.

34. Pub. L. No. 92-255, 86 Stat. 65 (codified as amended in scattered versions of 5, 21, and 42 U.S.C.)

35. 42 U.S.C. $\S 290$ dd- $2 ; 42$ C.F.R. $\S \S 2.1-.67$. Waiver of these requirements can be provided by patient consent and through other circumstances. $\S \S 2.31-.53$.

36. 41 U.S.C. § 702 (2000); see also Dep't of Labor, Drug-Free Workplace Advisor, http://www.dol.gov/elaws/drugfree.htm (last visited Aug. 15, 2008).

37. The medical profession has a much more comprehensive system of mandatory peer reporting. The Health Care Quality Improvement Act provides for a National Practitioner Data Bank. See 42 U.S.C. $\S \S 11101-15(2000)$. 
programs. Numerous decisions have clarified the application of Title II to character and fitness questions for both the legal and medical professions, but have reached differing results in challenges to those questions. The position of the licensing boards is that these questions are necessary to protect the public.

The first major decision to address the issue of character and fitness inquiries in the area of professional licensing was Medical Society of New Jerseyv. Jacobs. ${ }^{38}$ Although it involved medical licensing, it gave insight into how this issue would be treated by the courts. The district court, in an unpublished opinion, issued a preliminary order enjoining a state medical board from asking about alcohol or drug abuse and mental or psychiatric illness. The decision struck down broad mental health inquiries and suggested that questions should focus on conduct and capabilities. ${ }^{39}$ The decision also raised concerns about the additional burdens placed on applicants who responded affirmatively to the broad mental health inquiries. ${ }^{40}$

In the area of licensing for the legal profession, two major decisions addressed this issue. In an unpublished opinion, a district court in Texas upheld narrowly drawn questions asking about treatment for bipolar disorder, schizophrenia, paranoia, or any other psychotic disorder within the past ten years or since age eighteen, whichever time is shorter. ${ }^{41}$ A district court in Virginia provided a comprehensive listing of questions in all states for licensing and struck down a question about treatment or counseling for any mental, emotional, or nervous disorders within the past five years. ${ }^{42}$

As a result of greater attention to the issue, many questions asked by professional licensing agencies have been changed. ${ }^{43}$ The inquiries have been much more narrowly tailored to focus on behavior, conduct, and discipline, rather than asking about treatment status or diagnosis. They also have tended to narrow the timeframe. Some states ask only about conduct and current impairment. Other states, however, have recognized the deterrent effect of these questions and have eliminated these inquiries. Most states have not eliminated these questions but have only narrowed them to some degree, with

38. Civ. A. No. 93-3670 (WGB), 1993 WL 413016 (D.N.J. Oct. 5, 1993); see also D'Amico v. N.Y. State Bd. of Law Exam'rs, 813 F. Supp. 217 (W.D.N.Y. 1993) (applying the ADA to bar examiners).

39. See id. at *7.

40. See id. at *8.

41. Applicants v. Tex. State Bd. of Law Exam'rs, No. A 93 CA 740 SS, 1994 WL 923404 (W.D. Tex. Nov. 11, 1994).

42. Clark v. Va. Bd. of Bar Exam'rs, 880 F. Supp. 430, 446 (E.D. Va. 1995) (providing a comprehensive list of these types of questions asked by all state bar licensing authorities).

43. See generally RothsteIn \& RothsteIn, supra note 15 , § 5:8, at 510-12. 
many still asking about diagnosis and treatment. ${ }^{44}$ In spite of the changes to these questions, there is still strong concern that many of these questions deter students from obtaining needed counseling. ${ }^{45}$

More recent decisions have begun to address how disabilities are to be considered in the context of professional discipline. ${ }^{46}$ Courts have seemed willing to consider impairment as a mitigating factor in discipline and have focused on behavior and conduct, rather than status, in addressing these

44. For example, questions such as the following asked by the Oregon Board of Medical Examiners focus on current impairment, not diagnosis and history:

1. Do you currently, or have you had within the past 5 years, any physical, mental, or emotional condition which impaired, or does impair your ability to practice your health care profession safely and competently? Has there been any type of inquiry into your physical, mental, or emotional health within the past 5 years?

2. Within the past 5 years, have you been admitted to any hospital or other in-patient care facility for any physical, mental or emotional condition?

Oregon Medical Board, MD/DO/DPM Application for Licensure, Application Form, at 6 (Rev. 03/08), available at $\mathrm{http}: / / \mathrm{www}$. oregon.gov/OMB/MD-DO_Application/Application.pdf.

The North Carolina medical questionnaire asks:

In the past five (5) years, have you used alcohol or other substances in a manner that could in any way impair or limit your ability to practice medicine with reasonable skill and safety when on duty?

Do you have any medical conditions, other than substance abuse?

"Medical Conditions" Includes Physiologic, Psychiatric, Psychologic Conditions or Disorder,

Including but not limited to Orthopedic, Ophthalmologic, Neuromuscular Problems, Speech and

Hearing Impairment or Infectious Diseases.

North Carolina Medical Board, Graduate Medical Education Training License Application, http:// www.ncmedboard.org/Clients/NCBOM/Private/PhysicianApplication/PhysicianApplicationIntro.aspx? AppType $=$ NoFCVS (last visited May 12, 2008).

45. See Stanley Herr, Questioning the Questionnaires: Bar Admissions and Candidates with Disabilities, 42 VILL. L. Rev. 635 (1997), for a discussion of this issue. See also Jon Bauer, The Character of the Questions and the Fitness of the Process: Mental Health, Bar Admissions and the Americans with Disabilities Act, 29 UCLA L. Rev. 93 (2001); Kelly R. Becton, Attorneys: The Americans with Disabilities Act Should Not Impair Regulation of the Legal Profession Where Mental Health Is an Issue, 49 OKLA. L. Rev. 353 (1996); Mary Elizabeth Cisneros, A Proposal to Eliminate Broad Mental Health Inquiries on Bar Examination Applications, Assessing an Applicant's Fitness to Practice Law by Alternative Means, 8 GEo. J. Legal ETHics 401 (1995); Hilary Duke, The Narrowing of State Bar Examiner Inquiries into the Mental Health of Bar Applicants: Bar Examiner Objectives Are Met Better Through Attorney Education, Rehabilitation, and Discipline, 11 Geo. J. Legal Ethics 101 (1997); Jennifer McPherson Hughes, Suffering in Silence: Questions Regarding An Applicant's Mental Health on Bar Applications and Their Effect on Law Students Needing Treatment, 28 J. LEgaL Prof. 187 (2004) (reviewing recent literature).

A recent excellent review of this issue compares the manner in which impairment and licensure and discipline are treated and reviews the judicial responses to challenges to mental health and substance abuse questions on licensing questionnaires. See Yuri Walker, Protecting the Public: The Impact of the Americans with Disabilities Act on Licensure Considerations Involving Mentally Impaired Medical and Legal Professionals, 25 J. Legal Med. 441 (2004). A recent focus on this issue within the medical profession is found in Hendin et al., Licensing and Physician Mental Health, supra note*.

46. See generally RothsteIn \& RothsteIn, supra note 15, § 5:08, at 512 n.2. 
situations. Courts, however, recognize the responsibility to protect the public and therefore do not excuse misconduct even when related to a disability. ${ }^{47}$

\section{Regulatory Associations}

There are a number of organizations that play various roles in the regulation of the legal profession. ${ }^{48}$ To some degree, the differing roles these organizations play is one of the major factors that may hinder efforts to develop more effective policies and outcomes regarding mental illness and substance abuse.

The American Bar Association (ABA) is the accrediting body for law schools, designated by the Department of Education to carry out that function. $^{49}$ Virtually all state bar admission authorities require that an individual have a degree from an ABA-accredited law school in order to take the bar examination in that state. ${ }^{50}$ With respect to requirements that might relate to substance abuse and mental health issues, the ABA Standards for accreditation prohibit discrimination on the basis of disability. ${ }^{51}$ For most, if not all, law schools, this means that care is taken to ensure that questions in the admissions process do not ask about disability status but focus only on behavior and conduct.

The Association of American Law Schools (AALS) ${ }^{52}$ is not an accrediting body but rather a membership organization. Although many of its membership requirements are similar to the $\mathrm{ABA}$ accreditation standards, they

47. See Walker, supra note 45 , at 465 .

48. The medical profession is even more complex. Not only are there equivalents to the American Bar Association (the American Medical Association), the Association of American Law Schools (the Association of American Medical Colleges), and the National Conference of Bar Examiners (the Federation of State Medical Boards), but there are additional organizations such as the Accreditation Council for Graduate Medical Education (setting standards for residency programs, which require them to have mechanisms in place for mental health care), the Joint Commission on Accreditation of Healthcare Organizations, and others.

49. See American Bar Association, Legal Education and Admissions to the Bar, http:// www.abanet.org/legaled/ (last visited Aug. 15, 2008).

50. See generally Nat'l Conf. Bar Exam'rs \& ABA Section Legal Educ. \& Admissions to the Bar, Comprehensive Guide to Bar Admissions Requirements, at 10-16 (2008), available at http://www.ncbex.org/fileadmin/mediafiles/downloads/Comp_Guide/CompGuide.pdf [hereinafter BAR ADMisSions REQUiREMENTS].

51. See ABA Standards for Approval of Law Schools, Standards 211-212 (2007-2008), available at $\mathrm{http} / /$ www.abanet.org/legaled/standards/20072008StandardsWebContent/Chapter\%202.pdf [hereinafter ABA STANDARDS].

52. For more information on the AALS, see Association of American Law Schools, http:// www.aals.org (last visited Aug. 15, 2008). Its offices are located in Washington, D.C. 
are not identical. A law school benefits from AALS membership in terms of greater prestige and access to participation in AALS activities, such as conferences and publications. ${ }^{53}$ Like the ABA, the AALS requires that law schools not discriminate on the basis of disability. ${ }^{54}$ In effect, the expectations in the admissions and enrollment process are substantially similar to the ABA Standards.

The National Conference of Bar Examiners (NCBE) ${ }^{55}$ does not directly have accreditation or licensing authority. It does, however, provide expertise and technical assistance in a number of areas. It is an organization that offers services to state bar admissions authorities. These include four multistate bar examinations. The NCBE also does character and fitness screening for a number of jurisdictions and offers education on best practices in bar admissions to bar admission authorities. ${ }^{56}$ The perspectives of the organization are given great deference. The NCBE develops the multistate bar examination, which is used in the vast majority of states. Each state, however, makes its own determination about how to apply bar examination scores. State bar admissions agencies (which are established by various statutory and regulatory bases, such as by the state Supreme Court or by state legislation) set the requirements for licensure in each state. It is this body that determines the character and fitness requirements for initial licensure, retention of the license, and disciplinary action. Although these agencies are independent of any national organization, substantial deference is given to recommendations on a national level.

State licensing agencies are directly responsible for determining whether an individual meets the requirements to practice law in that jurisdiction. The licensing agencies are often guided by the ABA, AALS, and NCBE on setting

53. For example, the AALS publishes the AALS Newsletter four times a year. See AALS Newsletter, http://www.aals.org/services_newsletter.php (last visited Aug. 15, 2008). The AALS also has an annual meeting and provides clinics and workshops. See AALS, Events, http://www.aals.org/events.php (last visited Aug. 15, 2008).

54. See Ass'n Am. L. Schs., Inc., Bylaws of the Association of American Law Schools, $\S \S 6-2(\mathrm{c}), 6-3$ (amended 2004), available at $\mathrm{http}$ ://www.aals.org/about_handbook_bylaws.php. The AALS determined in its 1993 study of this issue that it was not "necessary or appropriate to recommend any changes in AALS Requirements of Membership ... to mandate that AALS member schools adopt any particular policies or programs concerning substance abuse." This was because the problems were too complex and the approaches too varied, and programs tailored to each law school were deemed best. 1993 AALS Report, supra note 4, at 37.

55. For information on the National Conference of Bar Examiners (NCBE), see http:// www.ncbex.org/ (last visited Aug. 15, 2008).

56. See Nat'l Conf. of Bar Exam'rs, NCBE Character and Fitness Services, http://www.ncbex.org/ character-and-fitness/services1/ (last visited Aug. 15, 2008). 
policy, but they are not mandated to follow the guidance. Some state agencies have defended broad questions in the initial licensing stage by indicating that applicants are rarely denied admission to the bar based on treatment for mental health or substance abuse problems. This argument ignores the fact that most applicants are unaware that there is a low risk of denial of admission where treatment (rather than misconduct) is at issue. Many are unwilling to risk their major investment of time and resources by seeking counseling that they would have to report. It may be true that in most states individuals will not lose their license nor be denied the license initially based on treatment, because there is not a national standard. Professional licensure applicants, however, may not know initially in what jurisdiction they plan to practice and seek admission. A consistent and comprehensive effort to educate law students that they should not be deterred from treatment may provide some assistance, but it is unlikely alone to address all of these concerns.

\section{LAw School Admission ANd Enrollment}

\section{A. Admission}

There are many more applicants than openings for admission to law school both nationally and for individual law schools. Admission to law school requires a strong academic record and other evidence of strong intellectual ability. One means of demonstrating that is the Law School Admission Test (LSAT), which focuses on verbal reasoning and analytical skills - not on acquired knowledge. Each law school determines for itself the significance of the LSAT score for admission to its program.

Admissions requirements are determined by the law schools themselves. The ABA Section of Legal Education and Admissions to the Bar sets standards for admission by virtue of being the agency authorized by the United States Department of Education to accredit law schools. Accreditation by the ABA is important because admission to practice law in each state generally requires having a law degree from an ABA-accredited law school. Although there are a number of unaccredited law schools, an individual who graduates from such a school may not be licensed to represent clients. The degree may provide background for other kinds of law-related work, but not the representation of clients.

The ABA accreditation standards for admission at each law school do not include requirements that directly pertain to mental health and substance abuse. They do prohibit law schools from discrimination on the basis of 
disability and include expectations of reasonable accommodations. ${ }^{57}$ Policies and procedures relating to these issues are developed by each law school. As institutions that prepare individuals to enter a profession of trust and honesty where members of the profession represent and provide services to clients about important matters, law schools have a strong interest in ensuring the character and fitness of those who enroll and those who graduate. The reputation of a law school with a state bar and with employers would be seriously compromised if the school failed to give proper attention to these issues. Law schools also are aware that they will be asked to certify the character and fitness of their graduates in the bar admission process.

All educational institutions have an interest in ensuring that the educational experience for all students is safe and not disruptive. This interest applies both to students with problems and others in the educational community who might be affected by students with problems. For all of these reasons, all law schools have policies, practices, and procedures in the admissions process (and throughout the enrollment period) that relate to character and fitness of students and graduates. Issues of mental health and substance abuse often bear on questions of character and fitness.

It is common practice for law school application forms to ask questions about criminal records and past undergraduate conduct violations (e.g., cheating, misconduct at student events). In recent years, law schools have become much more careful about how these questions are worded in order to comply with laws prohibiting discrimination on the basis of disability. ${ }^{58}$ Thus, questions asking about drunk driving incidents are common, but law schools are unlikely to ask if the student has been treated for alcoholism. Even if the criminal or other misconduct relates to a disability, it is probably legal to ask about misconduct. ${ }^{59}$

Some research has identified certain personality traits among lawyers that might affect behavior and conduct. ${ }^{60}$ Thus far, there has not been a move by law schools for applicants to be screened for certain behaviors and traits. ${ }^{61}$

57. See ABA StANDARDS, supra note 51, Standards 211-213.

58. 42 U.S.C. $\S 12182$ (b)(2)(A)(i) (2000) (prohibiting eligibility criteria that tend to screen out individuals with disabilities who are otherwise qualified).

59. There is very little litigation about these questions in the law school admissions process. See, e.g., Hash v. Univ. of Ky., 138 S.W.2d 123 (Ky. Ct. App. 2004) (denial of readmission); University of Illinois, 25 NAT'L DisABILITY L. ReP. $\mid 230$ (Dec. 20, 2002), available at 25 NDLR P 230 (Westlaw) (law school that did individualized review of all applicants did not have to modify its application process).

60. See Daicoff, supra note 1, at 1416-17.

61. There has been some discussion of this issue in the medical school context, however. See, e.g., Janice A. Knights \& Barbara J. Kennedy, Medical School Selection: Screening for Dysfunctional 
Before screening should be considered, substantial research would be needed to determine the validity and appropriateness of screening measures. Law schools should also be extremely careful in identifying the traits that are being screened and that appropriate individuals have made these determinations on a rationally justifiable basis. ${ }^{62}$

\section{B. Reporting After Enrollment}

Law schools do not have the resources to do criminal background checks themselves, so they do not generally independently verify criminal misconduct either before or during enrollment. A growing trend, however, is for student service administrators during the first few weeks of law school to advise students that this type of misconduct must be reported during the character and fitness certification process. Students are also advised that the bar authorities will do an independent background check, and that students who have been untruthful on their initial application to law school face more serious problems because of lack of candor. At this point, students are encouraged to come forward and correct any misstatements. The consequences of such postenrollment reporting on the student's continued enrollment status depend on the totality of the circumstances.

At most law schools, students are subject not only to honor codes imposed by the law school, but also to campus-wide student codes of conduct.

Tendencies, 40 MED. Educ. 1058-64 (2006) (reviewing current methods of selection; identifying negative personality characteristics not found in current selection process; suggesting method of screening to select; including a study of Australian medical students); Michael Weissberg et al., Medical Student Attitudes to Risk Taking and Self-Perceived Influence on Medical Practice, 40 MED. Educ. 722 (2006) (finding positive correlation between risk-taking and substance use and other issues; discussing implications for medical education; studying whether self-awareness of risk taking behavior would affect patient treatment through informed consent or otherwise); see also Reidar Wyssen et al., Factors in Medical School That Predict Postgraduate Mental Health Problems in Need of Treatment, 35 Med. Educ. 110 (2001) (in a study of Norwegian medical school students, finding previous mental health problems, not being married or cohabitating, personality traits "vulnerability" and "reality weakness," perceived medical school stress, and lack of perceived diagnostic skills); David C. Yao \& Scott M. Wright, The Challenge of Problem Residents, 16 J. GEN. InTERNAL MED. 486 (2001) (providing a comprehensive review of literature and data on problem residents; discussing impact of problem residents on other trainees); David C. Yao \& Scott M. Wright, National Survey of Internal Medicine Residency Program Directors Regarding Problem Residents, 284 J. AM. MED. Ass'N 1099 (2000) (identifying types of problems encountered and factors associated with identification and management of problem residents; most reported problems were insufficient medical knowledge, poor clinical judgment, inefficient use of time; identifying students who are from underrepresented minorities, international graduates, and those who are older as being at an increased risk of being identified as problem residents; positive interventions cited were frequent feedback, assigned mentor).

62. See generally Mark A. Rothstein et al., Employment Law, $\S 1.19$, at $43-45$ (3d ed. 2005). 
Campus conduct codes usually refer to activities such as misbehavior at a sporting event. Honor codes relate to matters such as plagiarism and cheating. Often, violations of the campus code of conduct are handled by university officials (with a system to report to the law school any findings and sanctions). Student honor-code matters are generally handled within the law school, and the results also become part of a student's record. The April 16, 2007 shootings at Virginia Tech University highlight the challenge of having various administrative agencies involved in conduct issues, which may not have systems to coordinate a response. ${ }^{63}$

In recent years, law schools have improved their methods of addressing issues relating to students with substance abuse or mental health problems. Most student-service administrators have a referral system either to a campus health program (where there is confidentiality for treatment) or to a private provider of services. Increasingly, law schools, in collaboration with state bar authorities, are developing systems of referring substance abuse problems to a Lawyer Assistance Program. ${ }^{64}$ This system is in the development stages. Little is known about the effectiveness of the program with respect to law students, and more research is needed to determine if programs originally designed for members of the profession work well for students.

Most, if not all, law schools require enrolled students to report criminal or campus misconduct during the time the students are enrolled. This means that a DUI occurring during a student's last semester of law school should be reported to the appropriate law school administrator. This misconduct would then be reported as part of the character and fitness certification to the bar admissions agency. Law students are generally not expected to report counseling or treatment received during law school to the administration. The exception might be for the law student requesting a leave of absence or other accommodation (such as a reduced course load or scheduling changes) for treatment. In that case, the law school might request documentation of the treatment to justify the accommodation.

63. See Va. Tech Review Panel, Report of the Review Panel: Mass Shootings at Virginia Tech (2007), available at http://www.governor.virginia.gov/TempContent/techPanelReport-docs/FullReport.pdf.

64. See generally American Bar Association, Commission on Lawyer Assistance Programs, http://www.abanet.org/legalservices/colap (last visited Aug. 15, 2008) [hereinafter ABA Comm'n on Lawyer Assistance Programs]. 


\section{Bar Certification Reporting}

One of the dilemmas for student-service administrators in law schools is the obligation to report character and fitness in the bar certification process. Virtually all state bar admission authorities ask some version of a question of the law school from where the student graduated about whether the law school has any knowledge about mental health or substance abuse problems. The wording of these questions varies from state to state. ${ }^{65}$ Thus, if a troubled student is referred to a campus health service or lawyer assistance program or an alcoholics anonymous program, the referring administrator may feel that he or she is required to report that fact. ${ }^{66}$ Even if the student does not go through the law school administrator to find the referral, the student will be asked a similar question in the bar admission process. This obligation to report is a deterrent to students seeking treatment. ${ }^{67}$

Another concern for the student is the confidentiality of the information. Although there is confidentiality between the student and the health-care professional providing counseling, the fact of a referral may be noted in the student's record. If a student takes a leave of absence or obtains a reduced course load or other accommodation because of the problem, the documentation to justify the accommodation will be in the student's file. The issue of who has access to the student's record raises a number of questions, many of which are not resolved by current law or general practice within legal education. These questions include: what faculty and staff members may review student records; what privileges there are to report information within

65. See Clark v. Va. Bd. of Bar Exam'rs, 880 F. Supp. 430, 438-40 (E.D. Va. 1995) (listing types of questions in each state).

66. For discussions of this issue, see Bauer, supra note 45. See also Hilary Duke, The Narrowing of State Bar Examiner Inquiries Into the Mental Health of Bar Applicants: Bar Examiner Objectives Are Met Better Through Attorney Education, Rehabilitation, and Discipline, 11 Geo. J. Legal Ethics 101 (1997); Stanley Herr, Questioning the Questionnaires: Bar Admissions and Candidates with Disabilities, 42 Vill. L. Rev. 635 (1997); Carol A. Needham, The Professional Responsibilities of Law Professors: The Scope of the Duty of Confidentiality, Character and Fitness Questionnaires, and Engagement in Governance, 56 J. Legal Educ. 106, 111 (2006).

67. See Allison Wielobob, Bar Application Mental Health Inquiries: Unwise and Unlawful, Hum. RTS. MAG. Winter 1997, at 15; 1993 AALS Report, supra note 4, at 54-55. The Law Student Survey pursuant to the AALS Report indicates that only 10 percent of students gave an unqualified positive response that they would seek help from a substance abuse program if they thought they had a problem. Forty-one percent would do so if assured that the information would not be available to bar officials. Id. at 55. This report reflected concerns of law school administrators about their obligation to report. It is probable that similar deterrence levels would be found for mental health treatment. 
the institution or to other institutions; and whether and how such access is to be documented or made known to the student.

A student with an addiction to controlled substances may be understandably concerned about reporting the addiction to the law school administration because it is unclear when and how that information will be reported in the bar certification process. There is a trend within state bar organizations to expand Lawyer Assistance Programs (LAP) that provide anonymous counseling to individuals with substance abuse and related problems. ${ }^{68}$ These programs are discussed in more detail below. There have been some recent efforts to make these services available to law students. Individuals who have been working to encourage law students to use the services need to understand that even though the LAP programs refer to themselves as "confidential," the students may still be required to report that they sought counseling. This, of course, is a deterrent, and an issue under study for improvement.

\section{Education}

One means of addressing problems that result from the stress of law school, including substance abuse, is to raise awareness of these issues at an early point during law school. The increased awareness by legal educators of the need to be proactive has resulted in an increase in information provided to law students at orientation, in handbooks, and in other forums within law school. ${ }^{69}$ The goal of such programs is to highlight for law students the signs of mental illness or substance abuse, the importance of seeking help when these problems occur, the resources available for assistance, and the consequences of not seeking help when it is needed. Raising awareness for all law students, not just those seeking help, is intended to decrease the number of students who get into trouble in the first place. ${ }^{70}$

Making law students aware of concerns about substance abuse and mental health problems is an important educational aspect of many law schools today. The 1993 AALS Report on Substance Abuse in Law Schools (AALS Report) indicated that a few law schools had undertaken such programs at that time ${ }^{71}$

68. See generally ABA Comm'n on Lawyer Assistance Programs, supra note 64 .

69. As of the 1993 AALS Report, only a few law schools had undertaken efforts on substance abuse in various educational programs. 1993 AALS Report, supra note 4, at 63-64.

70. Id. at 66-67. As of 1993, only about a quarter of law schools with university affiliations had substance abuse policies specific to the law school. Id. at 62 .

71. See id. at 64 . (Only $28.3 \%$ of law schools had undertaken such programs in 1993.) 
and noted that "law schools do not appear to be attacking the problem of substance abuse as aggressively as either the bar or the medical colleges." 72 It would be beneficial to determine the degree to which law schools currently provide educational programs and whether these programs have been evaluated. This information could be useful in identifying model practices. ${ }^{73}$

The AALS Report concluded with a number of recommendations, one of which was that law schools should develop written policies on substance abuse, even if the university has such a policy. ${ }^{74}$ The report recommended inclusion of the following elements in such a policy: general information about substance abuse and programs to combat substance abuse (including designation of a coordinator), educational and wellness programs, early intervention, counseling and treatment programs, information regarding the cost and financing of such programs, confidentiality for counseling and treatment programs, and disciplinary standards and sanctions. ${ }^{75}$ The recommendations compared the practice at law schools with that at medical schools, where wellness is incorporated more extensively into the education program. ${ }^{76}$ Although these issues are much more infused into medical school educational programming, "the effectiveness of medical education to the

72. Id. at 67.

73. See ABA Comm'n on Lawyer Assistance Programs, supra note 64.

74. 1993 AALS Report, supra note 4, at 71-76.

75. Id.

76. See id. at 74. For discussion of educational programs in medical schools, see Laura Weiss Roberts et al., Medical Student Illness and Impairment: A Vignette-Based Survey Study, 46 COMPREHENSIVE Psychiatry 229 (2005) (concluding that medical students have a pattern of preserving confidentiality of fellow medical students); Jenny Firth-Cozens, Interventions to Improve Physicians' WellBeing and Patient Care, 52 Soc. ScI. \& Med. 215 (2001) (following up on longitudinal study of medical students; suggesting model to addresses causes and symptoms of stress); Liselotte N. Dyrbye et al., Medical Student Distress: Causes, Consequences, and Proposed Solutions, 80 Mayo Clinic Proc. 1613 (2005) (discussing the unintended negative effects on medical students of training; indicating that stress increases during medical school and causes vary by year; providing suggestions for reducing stress in the education program; noting barriers to treatment); Jennifer Bennett \& Diarmuid O’Donovan, Substance Misuse by Doctors, Nurses, and Other Healthcare Workers, 14 Current Opinion Psychiatry 195 (2001) (summarizing of literature on substance misuse by healthcare workers; recommending that substance misuse issues should be included in training); Patrick G. O'Connor \& Anderson Spickard, Physician Impairment by Substance Abuse, 81 MED. CuINICs N. AM. 1037, 1040 (1997) (suggesting that residency directors may not focus on potential alcohol abuse among residents); Lila G. Croen et al., A Longitudinal Study of Substance Use and Abuse in a Single Class of Medical Students, 72 ACAD. MED. 376 (1997) (presenting a study of a class of medical students that resulted in conclusions that there was no evidence that substance use was a major problem, and that appropriate intervention, support and referral systems should held those few at risk; suggesting increased education to help all students to address this issue with peers and patients). 
students in preventing later dependencies has never been studied." "' Since the 1993 report, and in response to the report to some degree, there has been a trend to include more educational training in law schools. Even though this is a positive trend, both medical schools and law schools would benefit from assessment of whether programs work and if so, which ones are the most effective.

\section{E. Treatment}

There are four major issues with respect to treatment: the availability of treatment, information about the availability of the treatment, the affordability of the treatment, and confidentiality of the treatment. The AALS Report compared law school and medical school treatment programs on substance abuse. Because medical schools have a much longer history and more extensive programs of treatment during medical school, comparisons will be provided as available in the following discussion on treatment.

\section{Availability of Treatment and Knowledge of Availability of Treatment}

For law schools that are part of a university, there may be on-campus services available (with a wide variety of cost structures for these services). For those not part of a university, there may be agencies to which students are referred for professional treatment. One of the concerns raised in the AALS Report was that even where programs exist, law students do not necessarily know where to find them. ${ }^{78}$ It has become a more common practice within legal education to make known to law students the availability of treatment services. ${ }^{79}$

The AALS Report includes a substantial discussion of treatment programs in medical schools. The report includes a description of the history and status of a program known as the Aid for Impaired Medical Students (AIMS) Program, which has been adopted by all fifty state medical societies. ${ }^{80}$ The AIMS program goals stress a proactive approach by providing assistance before harm is done to a student. The ongoing tension between assisting the medical student and protecting the public is recognized in the design and implementation of the program. Aspects of the program include education at

77. Baldisseri, supra note 7, at S113.

78. 1993 AALS Report, supra note 4, at 66-67.

79. See id. at 63-64 (describing the practice as of 1993).

80. Id. at 51-52. 
student orientation sessions, peer counselor systems, and curricula on substance abuse. ${ }^{81}$

As one reviewer notes, "[F]or many physicians, substance abuse begins early during medical school and residency." 82 And while the incidence of drug and alcohol use may decrease as medical students continue their education, the use of certain substances may increase. The importance of a proactive approach to this issue is demonstrated by the finding that "for healthcare professionals, deterioration in clinical performance is one of the last signs of a substance use disorder." $" 83$

Medical schools, unlike law schools, are mandated to have treatment programs. The Higher Education Act of $1965^{84}$ requires medical schools to have policies and programs to address substance abuse among students. ${ }^{85}$ Most medical schools provide mental health services. ${ }^{86}$ These services are available either as part of general health services or through health insurance programs offered at the school. At four out of five medical schools, students are required to have health insurance. Access to these services, however, is affected primarily by time, cost, and concerns about confidentiality. Some programs require that the treatment be given at the training hospital, raising obvious concerns about confidentiality and stigma. ${ }^{87}$ The quality of these services has not been evaluated.

Medical school accreditation for residency programs requires mechanisms for providing mental health care. The program must be made known, and counseling services must be available. Thus, programs must exist and be

81. Id.

82. Baldisseri, supra note 7 , at $\mathrm{S} 109$.

83. Id. at S110 (citing S.J. Breiner, The Impaired Physician, 54 J. Med. Educ. 673 (1979) and G.E. Vaillant et al., Prospective Study of Alcoholism Treatment: Eight-Year Follow-up, 75 Am. J. Med. 455 (1983)) (discussing some of the conduct and behavior signs).

84. Pub. L. No. 89-329, 79 Stat. 1219 (codified as amended in scattered sections of 20 U.S.C.).

85. See 20 U.S.C. $\S 1002(2000)$

86. 2004 AAMC Survey of Housestaff Stipends, Benefits, and Funding, at 34-35 tbl.17 (2004), available at $\mathrm{http} / / \mathrm{www} . a \mathrm{amc} . \mathrm{org} / \mathrm{data} / \mathrm{housestaff} / \mathrm{hss} 2004 \mathrm{report} . \mathrm{pdf}$. The Association of Program Directors in Internal Medicine addressed the issue of residence substance use, recommending policies and procedures that include education and referral. Baldisseri, supra note 7, at S109.

87. See Jennifer Tija et al., Factors Associated with Undertreatment of Medical Student Depression, 53 J. Am. Coll. Health 219 (2005); Laura Weiss Roberts et al., Perceptions of Academic Vulnerability Associated with Personal Illness: A Study of 1,027 Students at Nine Medical Schools, 42 CoMPREHENSIVE PSYCHIATRY 1 (2001) (discussing health care needs, concerns about confidentiality, academic jeopardy, deterrence to treatment concerns); Meldon Kahan et al., Randomized Controlled Trial on the Effects of a Skills-Based Workshop on Medical Students' Management of Problem Drinking and Alcohol Dependence, 24 SuBStANCE ABUSE 5 (2003) (evaluating skills-based workshops in improving medical school student management of substance use and abuse; demonstrates short-term improvements). 
known, but use of them is not mandated nor necessarily ensured. Although it seems that medical students face a high level of stress and related mental health problems, they are quite reluctant to seek treatment. ${ }^{88}$ Several recommendations have been made for residency program directors and staff to address substance abuse problems in residents. ${ }^{89}$

Because there is no requirement of such services, legal education organizations should at least encourage law schools to provide or make available services. Although this is beginning to occur, it is not universal practice.

\section{Affordability of Treatment}

In general, cost has increasingly become an issue for access to health care. Student health insurance and student health programs often provide for only very basic services. Unless the student has more comprehensive, separately obtained health-care coverage, it may be prohibitively expensive to receive services, particularly counseling services. ${ }^{90}$ The AALS Report recognized cost as a concern, noting that student insurance may not cover all treatment, and free treatment may be limited. ${ }^{91}$ Because of students' concern for confidentiality, there are many cases in which students would prefer counseling off campus, but this may not be covered by student insurance policies. The result is that the student is deterred from seeking out the needed counseling. The AALS Report recognized this as an issue to be addressed. ${ }^{92}$

88. See Weiss Roberts et al., supra note 87 , at 2 .

89. O'Connor \& Spickard, supra note 76, at 1040. These are:

(1) Establish an organized process to address substance use.

(2) Educate housestaff and attending faculty about medical center policies concerning substance use.

(3) Orient residents and their families concerning substance use among physicians.

(4) Define a process for referral and self-referral of residents with substance use problems.

(5) Educate residents and staff physicians on how to seek help for a resident who is suspected of substance abuse.

Id.

90. The ADA allows for differential coverage justified on legitimate actuarial data or reasonable experience. For cases on this issue, see Rothstein \& Rothstein, supra note 15, § 10:2, at 689 n.13.

91. 1993 AALS Report, supra note 4, at 64 .

92. Id. at 53-58. 


\section{Confidentiality of Treatment}

Confidentiality is key to the success of treatment programs..$^{93}$ The AALS Report recognized the tension between the duty to protect the public and the deterrence to treatment if the student thinks the treatment must be reported and that it will impact licensure adversely. The medical school setting includes an expectation of reporting certain kinds of impairment, but concerns about confidentiality are a deterrent. "Colleagues and staff members may be reluctant to report their suspicions for many reasons: intimidation, fear of occupational and financial reprisals, and the need to protect the physician's practice or the hospital's reputation." ${ }^{\prime 94}$

The AALS Report noted the problem for law school administrators in advising students about the degree to which counseling must be reported, especially in light of the many ways this is treated by each state. ${ }^{95}$

\footnotetext{
Students were asked whether they would seek assistance from a law school or university substance abuse program if they believed that they had a substance abuse problem. Only 10 percent answered an unqualified yes. But 41 percent responded that they would seek assistance if they were assured that bar officials would not have access to the information. ${ }^{96}$
}

A similar response differential was demonstrated regarding whether a student would refer a fellow student for treatment. ${ }^{97}$ The response by law school administrators about whether they could, should, or must report information about substance abuse also indicated the dilemma faced in making these referrals or counseling students. ${ }^{98}$

93. See Dyrbye et al., supra note 76 , at 1614 . The study suggested as additional barriers: "lack of time, perception of academic jeopardy, ... the stigma of mental illness, and cost." Id. It also noted greater barriers for women and minorities.

94. Baldisseri, supra note 7, at S111.

95. 1993 AALS Report, supra note 4, at 54 .

96. Id. at 55 .

97. See id.

98. See id. 


\section{The ABA Approach to Treatment Issues}

In 1988, the ABA established the Commission on Impaired Attorneys. ${ }^{99}$ The goal of the organization was to help attorneys with addiction impairments. A result of that effort is that every state has established a lawyer assistance program or similar committee. ${ }^{100}$ The AALS Report prompted the creation of the ABA Commission on Lawyer Assistance Programs (CoLAP) and, in 2002, the establishment within CoLAP of a Law School Outreach Committee. ${ }^{101}$ The goal was to reach lawyers at an early stage — law school. ${ }^{102}$ Among other projects, CoLAP has developed a "tool kit" to provide law school administrators a resource guide to deal with substance abuse issues in their law schools. ${ }^{103}$ These tools are also useful for mental health problems. The tool kit provides information on developing substance abuse policies and procedures, prevention, education, intervention, treatment, and a directory of Lawyer Assistance Programs.

More recently, the CoLAP Law School Outreach Committee has engaged in efforts to propose a model rule on conditional admission to the practice of law. ${ }^{104}$ The model rule recognizes the need to protect the public as well as the importance of having constructive rehabilitation models where mental illness or substance abuse has resulted in unfitness to practice law and where the conduct or behavior may be likely to recur. The rule targets applicant behavior, conduct, and other impairment, not the fact that an individual is receiving treatment. ${ }^{105}$ It recommends a conditional admission process that would encourage an individual to seek early treatment and provide for a confidential conditional admission process with an effective monitoring procedure to act more quickly if there is a relapse. ${ }^{106}$ The proposal includes

99. The name was changed to the Commission on Lawyer Assistance Programs (CoLAP) in 1996. See ABA, Commission on Lawyer Assistance Programs, Commission Activities, http://www.abanet.org/ legalservices/colap (last visited Aug. 15, 2008) [hereinafter CoLAP Commission Activities].

100. See supra Part V.

101. See CoLAP Commission Activities, supra note 99.

102. Letter from Richard A. Soden, Chair of the ABA CoLAP, to law school deans (Dec. 9, 2005) (on file with author).

103. More information on the tool kit is available at http://www.abanet.org/legalservices/colap/ publications.html (last visited Aug. 15, 2008).

104. For information on this work, see CoLAP Law School Assistance Committee to Submit Proposed Model Rule to ABA House Of Delegates, Highlights (ABA Comm'n on Lawyer Assistance Programs, Chi., Ill.), Fall 2006/Winter 2007, at 1, available at http://www.abalegalservices.org/colap/highlights/ highlightsfall06winter07.pdf.

105. See id. at 2-3.

106. Id. at 1. 
provisions to make information about the conditional admission process publicly available. ${ }^{107}$ Lawyer Assistance Programs or other bar or legal organizations that provide support to lawyers are to have the primary responsibility for educating students, law school administrators, and bar applicants about these issues and are to identify resources to address such concerns. ${ }^{108}$ The Admissions Authority of each state is expected to cooperate reasonably in these efforts. ${ }^{109}$

\section{F. Discipline}

Law schools, and the universities with which most are affiliated, all have disciplinary codes that address law school honor code violations, misconduct in law school activities, misconduct in university sports functions, misconduct in university housing, and criminal misconduct on or off campus. Although in some instances the misconduct may be related directly or indirectly to a disability (e.g., alcoholism, drug addiction, mental illness), the disability does not excuse the behavior.

Courts and the Department of Education Office for Civil Rights are consistent about permitting disciplinary action even where the misconduct relates to a disability. ${ }^{110}$ There is, however, some recognition in certain instances that the disability might be considered as a factor in mitigating the sanction. The AALS Report noted some innovative programs that include sanctions tailored to substance abuse. ${ }^{111}$

Law schools that have clinical programs where students have direct client contact may need to focus particular attention on the issue of discipline and

107. Id. at 10 .

108. $I d$.

109. $I d$.

110. RothsteIN \& Rothstein, supra note $15, \S 3: 3$, at 274-79 \& $\S 5: 8$, at 510-12.

111. 1993 AALS Report, supra note 4, at 66. Some of these include graduated sanctions and referral to rehabilitation programs. The report notes that a system of graduated sanctions could send a message to students that certain offenses are more serious than others. For comparisons with medical school discipline, see Hall et al., supra note 4 (citing excessive use of alcohol by medical students; hypothesizing that use of alcohol during medical school adversely affects later treatment and that early onset of addiction is most difficult to treat); Gregory B. Collins et al., Chemical Dependency Treatment Outcomes of Residents in Anesthesiology: Results of a Survey, 101 ANESTHESIA \& ANALGESIA 1457 (2005) (discussing prevalence of impaired anesthesiology residences; suggesting redirection of rehabilitated residents into lower-risk specialties based on particular challenges in anesthesia specialization); Dyrbye et al., supra note 76 (study suggesting that mental health worsens after beginning medical school and is poor throughout; stress can add to substance abuse, broken relationships, suicide, and attrition). 
sanctions where student misconduct occurs. This has been raised as a concern but has yet to be definitively addressed. ${ }^{12}$

\section{Professional Licensing}

\section{A. Initial Licensing}

Although an individual with a law degree may choose to do work that does not require professional licensing, the vast majority of those who graduate expect to be in a position where they can represent clients. In order to do so, law school graduates must be admitted to the bar. Licensing is handled exclusively by the states. Although many states allow for reciprocal arrangements and transfers, all of these arrangements must be approved by the state in which the individual wishes to practice law.

The primary prerequisite to obtaining a license is having a professional degree from an ABA-accredited law school. To obtain a legal profession degree (the Juris Doctor or J.D.), a program generally requires three years of study (four years for part-time programs). ${ }^{113}$ Clinical education in which actual clients are served is not a required aspect of legal education. Although it is not unusual for law students to complete their J.D. without ever having had a clinic experience, there is a trend towards infusing more practical skills into the law school curriculum, with most law schools offering clinical education. In addition to clinical education (in which a faculty member and/or a practicing attorney have direct supervision of client contact), many law schools provide externships or other placement programs through which law students (under the supervision of a practicing attorney or judge and with direction from a faculty member) handle legal matters for real clients.

Individuals take the bar examination in the state in which they wish to practice only after completing the J.D. and graduating from law school. ${ }^{114}$ Although the current examination focuses on substantive knowledge, there is a trend towards developing tests that evaluate practical skills and the application of knowledge. Those seeking admission to practice must also

112. See Needham, supra note 66, at 111-14; John M. Burman, Alcohol Abuse and Legal Education, 47 J. LEgal Educ. 39 (1997) (law faculty member supervising student in legal services program commenting on student who was an active alcoholic).

113. Although many law schools also offer advanced legal education degrees (Masters of Law or LL.M.) for specialized areas or foreign lawyers, the J.D. is generally the only credential required for licensure.

114. However, some states do permit students to take the bar exam before graduation. See BAR Admissions ReQUiREMENTS, supra note 50, at 3 chrt.1. 
generally pass an examination testing knowledge of professional responsibility. Although portions of the bar examination and the professional responsibility examination are developed by the $\mathrm{NCBE},{ }^{115}$ the decision to use these or other questions and the required score for admission is set by each state.

In addition to having the requisite competence, a critical aspect of certification to practice law in each state is having the necessary character and fitness. Lawyers hold a high position of trust and are officers of the court. For that reason, character is an important part of the evaluation criteria for the state licensing board (which is often an instrument of the state supreme court, but which is always a state government agency of some type). Virtually all state bar licensing authorities ask a range of questions relating to criminal misconduct, financial affairs, and other matters relating to integrity. The area of controversy for this discussion involves questions about mental health and substance abuse. ${ }^{116}$

\section{B. License Retention and Discipline}

Although license retention requirements vary by state, most states require annual completion of some type of continuing legal education. Lawyers are not required to retake any type of examination to retain their license. Disciplinary actions, however, may be a trigger for licensing removal or other sanctions, such as probation or monitoring. In most states, disciplinary action may commence in a number of ways, including peer reporting, judicial referral, and complaints by the public (including clients). ${ }^{117}$

In many instances, disciplinary action for lawyers can trigger mandatory treatment. Even if treatment is not mandatory, there has been increased attention to the importance of having effective treatment for impaired legal

115. See notes 56-57 and accompanying text.

116. See supra Part III.C.

117. See generally Diane M. Ellis, A Decade of Diversion: Empirical Evidence That Alternative Discipline Is Working for Arizona Lawyers, 52 EMORY L.J. 1221, 1221-37 (2003) (comparing statistical analysis of data on diversion-assistance programs to prosecutorial disciplinary proceedings, concluding that diversion programs provide greater benefits); Hamilton P. Fox III \& Michael J. Crowley, Alcoholic Lawyers: Are They Being Coddled by Attorney Discipline Systems?, A.B.A. J., Jan. 1996, at 38-39 (discussing the pros and cons of allowing alcoholism to mitigate punishment); Freeman, supra note 5, at 9-21 (examining the linkage between lawyer impairment and ethical misconduct, as well as the ethical problems in reporting); John Levin, The Mentally Impaired Lawyer: What Is Our Obligation To Report?, CHI. Bus. Ass'N ReC., Jan. 2004, at 54 (reviewing ABA opinion on the duty to report impaired lawyers in the context of the Illinois Rules of Professional Conduct). 
professionals. However, little evaluation has been done regarding the relationship between disciplinary complaints, malpractice claims, and alcoholism. ${ }^{118}$

\section{Treatment}

Whether treatment as part of a disciplinary process is mandatory, voluntarily sought, or only encouraged by peers or others, both the legal and medical professions have increasingly focused on developing treatment programs. ${ }^{119}$ In 1988, the ABA began a concerted effort to focus on treatment. The commission developed two reports. In 1990, the ABA adopted the commission's Model Law Firm/Legal Department Personnel Impairment Policy and Guidelines, ${ }^{120}$ and in 1991 it adopted the Guiding Principles for a Lawyer Assistance Program. ${ }^{121}$ These reports focused on help and treatment rather than discipline. ${ }^{122}$ They also recognized the critical element of

118. See Maureen Hynd, A Friend in Need May Be a Malpractice Claim Waiting to Happen, Risk Mgmt. Rep. (ALPS Corp., Missoula, Mont.), Nov. 26, 2003, available at http://www.alpsnet.com/ LegalNews/ViewArticle/tabid/88/articleId/92/Default.aspx. The author relates that Oregon is the only state to have studied the relationship between disciplinary complaints, malpractice claims, and alcoholism and to have published the results. The results indicate that malpractice claims and disciplinary complaints were four times higher before recovery than after recovery, and that lawyers in recovery have lower disciplinary and malpractice claim rates than the overall lawyer population.

119. See generally Resner, supra note 3 (summarizing The Other Bar and the Lawyer Assistance Program and the success rates and barriers for each); Janet Piper Voss, Helping Lawyers, Judges and Law Students: Lawyers' Assistance Program Celebrates 25 Years, Chi. B. Ass'N Rec., Oct. 2005, at 49, 64 (summarizing how the Lawyers Assistance Program in Chicago works to provide assistance and education based on twenty-five years of experience of the author); Timothy J. Sweeney et al., Treatment for Attorneys with Substance Related and Co-occurring Psychiatric Disorders: Demographics and Outcomes, 23(1) J. ADDictive Diseases 55 (2004) (a clinical study of professionals treated for substance-related psychiatric disorders comparing the treatment of legal and healthcare professionals, concluding that attorneys leave treatment prematurely in greater numbers and suffer a higher incidence of co-occurring psychiatric disorders).

120. See ABA Comm'n on Impaired Attorneys, Committee on Lawyer Competence, Report to the House of Delegates (1990), available at http://www.abanet.org/legalservices/downloads/colap/ modellawfirm.pdf.

121. See ABA Comm'n on Lawyer Assistance Programs, supra note 64 ("[T] $]$ he Commission has been quite successful in aiding the introduction and support of programs in both state and local bars. Whereas only twenty-six state bar programs existed in 1980, today all fifty states have developed lawyer assistance programs or committees focused on quality of life issues. These programs employ the use of intervention, peer counseling, and referral to 12-Step Programs to assist in the lawyer's recovery process."); see also ABA Comm'n on Lawyer Assistance Programs, Comm'n on Mental \& Physical Disability Law, Standing Comm. on Substance Abuse, Model Lawyer Assistance Program (adopted 2004), available at http://www.abanet.org/legalservices/downloads/colap/2004abamodellaprevised.pdf(CoLap Model Lawyer Assistance Program adopted in 2004).

122. 1993 AALS Report, supra note 4, at 49-51. 
confidentiality in ensuring that lawyers are not deterred from treatment based on chemical dependency alone.

Other efforts at both the national and state levels have focused on a variety of measures to balance the support of the impaired individual with the public's interest in competent representation. These efforts include allowing substance abuse to be a mitigating factor in attorney discipline, a variety of educational programs, and technical assistance in responding to individual cases. The AALS Report noted that "the most effective lawyer assistance programs have implemented many or all of the ABA Commission's Guidelines ... [and emphasize] three areas for action: education; assistance with diagnosis, intervention, and treatment; and assistance with aftercare and recovery." 123 The AALS Report also noted the need for additional work in the area of confidentiality, immunity for those involved in intervention, implementation of impairment as discipline mitigation, and involvement in aftercare. ${ }^{124}$

The work of the ABA on a Model Rule on Conditional Admission to Practice Law was referenced earlier. ${ }^{125}$ The purpose of the model rule is to balance the interests of the individual and the public. The proposed model rule was approved at the February 2008 mid-year meeting of the ABA.

The issue of treatment for medical professionals, previously discussed, has been studied to a much greater degree than similar programs for lawyers. ${ }^{126}$ One study has suggested that the ideal components of an effective

123. Id. at 49 .

124. Id. at 50 .

125. See ABA, Model Rule on Conditional Admission to Practice Law (2008) available at http://www.abanet.org/legalservices/downloads/colap/ABAModelRule_ConditionalAdmission_Feb200 8.pdf. The National Conference of Bar Examiners and the Council of the ABA Section of Legal Education and Admissions to the Bar both expressly endorsed the proposed Model Rule and were co-sponsors before the ABA House of Delegates, along with a number of other cosponsors. See also supra Part III.E.4.

126. See, e.g., JeAn Kinney, Chapter 22: Impaired Health Care Professionals, in Clinical Manual of SubStanCE ABuSE, at 349-61 (Jeff Burnham ed., Mosby-Year Book, Inc. 1996) (1991) (identifying risk factors, signs and symptoms, steps for intervening, and the use of impaired professional programs); Baldisseri, supra note 7 (presenting data on the substance abuse of healthcare professionals and reviews programs designed to assist them with reentry into practice); Michael Gossop et al., Health Care Professionals Referred for Treatment of Alcohol and Drug Problems, 36 Alcohol \& Alcoholism 160 (2001) (a study of the treatment of sixty-two health care professionals demonstrating that referral generally resulted from intoxication at work or chronic absenteeism and that only slightly more than half completed treatment); Kostas A. Katsavdakis et al., Profiles of Impaired Health Professionals, 68 Bull. MenNinger CLINIC 60 (2004) (describing the problems, most commonly marital and emotional, that lead health care professionals to seek treatment, the sources of referral for the treatment, and the recommended proactive steps by licensing and regulatory agencies to identify those who may be at greater risk); Marcy Willard Long et al., Prevention of Relapse in the Recovery of Arizona Health Care Providers, 25(1) J. ADDICTIVE DISEASES 65 (2006) (examining factors that encourage health care providers to relapse into active chemical 
treatment program for physicians include immediate intervention, evaluation and triage to an appropriate facility, uninterrupted therapy, family involvement, rapid reentry into practice, close monitoring, and disaster plan contingency. ${ }^{127}$ It would be useful to know if similar components would be effective for lawyers. There are programs in some states that have been in place for several years, and these programs would provide opportunities for assessing their effectiveness. Part of the challenge for doing so, however, is determining how to measure success.

\section{EMPLOYMENT}

As noted previously, although most law school graduates choose to serve clients, some graduates seek other employment. Graduates often become involved in business, political activities, and government agencies in ways that do not necessarily require a license. Prospective and current employers of all graduates have a clear interest in ensuring that those employed are competent technically and have the requisite character and fitness. For that reason, these employers have used a number of mechanisms to ensure this result.

Employers of lawyers have little direct access to information about mental impairment and substance abuse. In all employment settings, at the pre-employment stage, disability discrimination laws affect what a prospective employer can inquire about an individual's mental illness or substance abuse. ${ }^{128}$ The ADA and EEOC regulations pursuant to the ADA provide information about what, when, and how an employer can learn about impairment. ${ }^{129}$ Further guidance exists on pre-employment medical examinations and medical examinations after a conditional offer of

dependency and suggests further study); Susan V. McCall, Chemically Dependent Health Professionals, 174 W.J. MED. 50 (2001) (suggesting the counter-productivity of disciplinary action and discusses the physician health programs that most states have developed to provide confidential rehabilitation); Monahan, supra note 8 (discussing treatment and raises issues for future research); Howard B. Roback et al., Confidentiality Dilemmas in Group Psychotherapy With Substance-Dependent Physicians, 153 AM. J. Psychiatry 1250 (1996) (discussing the use of group therapy with impaired physicians and the confidentiality problems that create a risk of social and professional injury; proposes model legislation); Gregory Skipper, Treating the Chemically Dependent Health Professional, 16(3) J. AdDiCtive DisEASES 67 (1997) (discussing adverse consequences of mismanaging chemical dependence treatment for physicians, concluding that programs require firm boundaries, time, and patience).

127. O'Connor \& Spickard, supra note 76, at 1046-49.

128. RothsteIn \& Rothstein, supra note $15, \S \S 4: 17$ to :18, at $434-42$.

129. 42 U.S.C. $\$ 12112$ (2000); 29 C.F.R. $\$ 1630.1$ to 16 (2007); see also RothSTEIN \& RothSTEIN, supra note $15, \S \S 4: 18$ to :19, at $436-44$. 
employment has been made. ${ }^{130}$ Post-offer medical exams are allowed if all employees in the same job category are subject to the examination. ${ }^{131}$ Drug tests are not considered medical examinations and are neither required nor prohibited. ${ }^{132}$

Once employed, individuals in all employment settings must be otherwise qualified to carry out the essential functions of the position with or without reasonable accommodation. ${ }^{133}$ An individual who poses a direct threat to self or others who cannot be reasonably accommodated is not considered to be otherwise qualified. ${ }^{134}$ An individual who is currently using illegal drugs or illegally using legal drugs is also unprotected. ${ }^{135}$

Employers that base adverse actions on impermissible or unacceptable behavior, performance, or conduct (even if that deficiency is related to a substance addiction or to a mental health impairment) are not in violation of disability discrimination law. ${ }^{136}$ Although employers might be encouraged to take such impairments into account in discipline, they are not required to do so. ${ }^{137}$

\section{RECOMMENDATIONS}

Beginning in the late 1980s and early 1990s, the legal profession began to recognize the significant impact that substance abuse and mental health problems were having on lawyers and on the public served by those individuals. A greater awareness and a greater attention to addressing the issue certainly exist today. In many ways, there has been progress. New education and treatment programs and new policies on discipline have been adopted. Furthermore, there is a longer record of experience with programs that were in place in the 1980s and 1990s. What is needed at this point is greater attention to evaluating and assessing these policies and programs. In many areas, a more viable means of data and information sharing among law

130. See 29 C.F.R. $\S 1630.14$.

131. Id. § 1630.14(b).

132. Id. $\S 1630.16(\mathrm{c})$.

133. 42 U.S.C. § 12111(8); 29 C.F.R § $1630.2(\mathrm{~m})$.

134. 42 U.S.C. $\$ 12111(3) ; 29$ C.F.R. § 1630.2(r).

135. 42 U.S.C. § 12114; see also RothsteIN \& RothsteIn, supra note 15, § 4:09, at 401-04.

136. See Rothstein \& Rothstein, supra note $15, \S 4: 16$, at $432-34$, $5: 8$, at 510-12, $\S 10: 03$, at 692-703.

137. See generally Laura F. Rothstein, The Employer's Duty to Accommodate Performance and Conduct Deficiencies of Individuals with Mental Impairments Under Disability Discrimination Law, 47 Syracuse L. Rev. 931 (1997). 
schools, employers, bar associations, licensing agencies, and the different states and national organizations would be helpful. As work continues on these issues within the legal profession, it will be important that the various parties engage in ongoing communication and collaboration (where possible) to establish sound policies, practices, and procedures. Although parties at different levels have different goals and expectations, information sharing and discussion may enhance the achievement of these goals for all.

A comprehensive analysis of the effectiveness of many of these programs and policies is not yet available. Even though much work has been done, there is not yet sufficient experience or assessment of programs to identify best practices. It would seem, however, that there is an opportunity to begin evaluating these programs and publishing the results of those assessments and recommending model practices. There are, however, some areas in which more is known than other areas. The following is a general set recommendations for areas where additional research and other efforts would be beneficial.

\section{A. Collection of data}

\section{Prevalence of Mental Illness and Substance Abuse}

Additional research is needed about the prevalence of impairment and whether there are particular areas of practice where the individual is more likely to have impairment issues relating to mental health or substance abuse. Research on different practice areas could identify areas of particularly high stress and possibly facilitate determining what interventions (education, treatment, or discipline) are most effective for lawyers who practice in these areas. Gender and ethnic differences could be explored as well.

\section{Impact of Stress}

Related to the prevalence of impairment is the impact that stress has on professional education and professional practice. ${ }^{138}$ What occurs that is stressful during law school that might be changed to produce less stress?

138. See generally Daicoff, supra note 1; see also Liselotte N. Dyrbye et al., Personal Life Events and Medical Student Burnout: A Multicenter Study, 81 ACAD. Med. 374 (2006) (concluding that both personal and curricular factors relate to burnout among medical students). More study is needed on student well-being and the impact of stress. See Dyrbye et al., supra note 76 (suggesting the need for research to identify factors affecting well-being). 
What factors reduce stress for different professions and different subgroups and at different points in the process? ${ }^{139}$

\section{B. Education}

What does the research demonstrate about the benefits of education programs about mental health and substance abuse? ${ }^{140}$ For example, the medical profession mandates education during medical school, but is there evidence that it works, that some programs work better than others, or that it is more effective at a particular point in the education? What is known about the best timing to reach students? When are they most receptive to recognizing depression in themselves and others? What will motivate them to seek counseling or treatment? If this information is not available, it would be useful to develop studies to gain that information. Many law schools have started educational programs on these issues. Have they followed up to evaluate these programs? Is anyone gathering this information? What would be the best means of gathering and sharing the best practices?

\section{Treatment}

There are a number of treatment programs for lawyers and law students. Which ones are most effective? ${ }^{141}$ What means exist to share information about these treatment programs with others who might wish to implement them? What do we know about what does not work? Do treatment programs that work for lawyers necessarily mean that they will be effective for law students? Are their interests different? Are their stressors different? What lessons can be drawn from the medical profession?

Ensuring access to treatment programs is equally critical. This Article has identified concerns about the availability of treatment programs and

139. See generally Krieger, supra note 8 (discussing issues of balance and how to address such issues in the academic process).

140. See generally Bennett \& O'Donovan, supra note 76 (recognizing that the risk of substance misuse should be included in training healthcare workers and that specialist treatments should be holistic and include the treatment of depression, anxiety, sexual disorders, and adjustment disorder); R.H. Coombs, Drug Abuse Prevention for Trainees in the Health Professions, 3 J. Substance Misuse 42 (1998) (reviewing current and past programs at health science centers intended to prevent substance abuse).

141. See generally Kristy N. Bernard \& Matthew L. Gibson, Professional Misconduct by Mentally Impaired Attorneys: Is There a Better Way to Treat an Old Problem?, 17 Geo. J. Legal Ethics 619 (2004); Sweeney et al., supra note 119; Fred C. Zacharias, A Word of Caution for Lawyer Assistance Programming, 18 Geo. J. Legal Ethics 237 (2004). 
information regarding such programs, the affordability of treatment (with challenges related to health insurance limitations), the confidentiality of treatment, and the licensing requirements that mandate the reporting of treatment. What is most needed in this area is to evaluate the political, practical, and economic reasons why these barriers remain. Policies and procedures that mandate reporting treatment should be reexamined to develop procedures that focus on behavior and conduct, rather than diagnosis and status.

It has been suggested that the ideal components of an effective treatment program for physicians include immediate intervention, evaluation and triage to an appropriate facility, uninterrupted therapy, family involvement, rapid reentry into practice, close monitoring, and disaster plan contingency. ${ }^{142}$ Are these also the ideal components for the legal profession? The mandatory aspect of clinical training for medical students is the basis for mandating treatment programs and various reporting requirements during medical school. Should law schools take a close look at the degree to which client contact through law school clinics might also necessitate such treatment and reporting?

\section{Licensure and Discipline-Determining Competence}

The initial licensing process includes completing an accredited academic program, taking a licensing exam, and demonstrating the requisite character and fitness to practice. The recent work on evaluating performance (not just academic knowledge) for licensing within the medical profession only seems to be in the beginning stages within the legal profession. Perhaps it is more difficult to determine essential functions for lawyers and to infuse preparation into legal education because law school graduates are more likely than similarly situated medical school graduates to use their legal training for work other than representing clients.

Attention to the issue of mental health and substance abuse during law school is key to evaluating how issues of mental health and substance abuse affect competency (which includes character and fitness). A recent study of the medical profession concluded that prior behavior in medical school (particularly certain types of behavior) was predictive of unprofessional behavior in practice. ${ }^{143}$ This study might be the basis for considering whether

142. See O'Connor \& Spickard, supra note 76, at 1046.

143. Maxine A. Papadakis et al., Disciplinary Action by Medical Boards and Prior Behavior in 
more attention should be paid to misconduct during professional education for lawyers.

In addition to initial licensure, issues of license revocation and other disciplinary measures should be reviewed and evaluated. ${ }^{144}$ Are there programs of conditional licensing, probationary licensing, and similarly supervised situations that work? What are the costs and benefits of such programs? Are mandates to report misconduct by peers counter-productive because the sanctions for being impaired are so severe? ${ }^{145}$ The medical profession procedures can provide a comparison. ${ }^{146}$

\section{CONCLusions}

This Article asks many more questions than it answers. Although there is a great deal of research and information on these issues, it is difficult to synthesize and assess what is working. The 1993 AALS Report on Substance Abuse was an excellent review of key issues, but it is now fifteen years old and has not been updated. The ABA CoLAP program followed up on many of the recommendations, but there is a significant need to assess the programs that have been implemented and to share information about those assessments.

National organizations are in the best position to gather and review comprehensive information and to provide information on best practices. A joint task force of law school representatives, national legal education organizations, legal employers, and licensing and other agencies could help to address some of these issues. Such a task force should review the literature,

Medical School, 353 New ENG. J. Med. 2673 (2005) (noting irresponsibility, diminished capacity for selfimprovement, and poor initiative as raising particular concern).

144. See generally Brooke, supra note 7 (describing the mechanisms for assisting impaired professionals in treatment, the separation of disciplinary procedures from treatment, and the self-help groups that play a crucial role in therapy); CоомBs, supra note 3 (describing essential components to recovery, including self-help programs (12-step programs)); Ellis, supra note 117 (describing the twentyfive year history of diversion programs, including their elements, successes, and benefits); Freeman, supra note 5 (discussing how impairment is manifested, how it can be unethical, and the necessary client consent for reporting).

145. See generally Robert Dowers, Duties Invoked Under the Model Rules of Professional Conduct by a Mentally Impaired Lawyer, 19 Geo. J. Legal Ethics 681 (2006); Kenneth L. Jorgensen, Ethical Responsibilities for an Impaired Partner, BENCH \& B. MinN., Oct. 2003, at 12; Levin, supra note 117; Eileen Libby, Sharing the Consequences: A Lawyer's Mental Impairment Raises Ethics Issues for Other Members of the Firm, A.B.A. J., July 2003, at 32.

146. See Timothy S. Jost et al., Consumers, Complaints, and Professional Discipline: A Look at Medical Licensure Boards, 3 Health Matrix 309 (1993) (concluding that very little is known about medical board disciplinary activity, particularly regarding who complains, the investigation process, and the outcomes). 
determine what areas would benefit from more research, and develop a mechanism for accessing best practices for education, treatment, and discipline. Political and other institutional barriers to implementation of effective practices should be assessed and strategies identified to overcome such obstacles.

The problems have been recognized. Steps have been taken to address them. It is time to determine whether those steps are working, and to share information about what is working. Where there is a need for further action, it should be pursued, and an evaluation of that action should be part of its implementation. Progress has been made in addressing the issue of law student and lawyer mental illness and substance abuse, but more remains to be done. 